\title{
COMPOSIÇÃO SOCIAL, CRITÉRIOS DE SELEÇÃO E LÓGICAS DE RECRUTAMENTO DA ELITE MÉDICA EM SERGIPE*
}

\section{Fernanda Rios Petrarca ${ }^{1}$}

(D) https://orcid.org/0000-0003-1351-3043

${ }^{1}$ Departamento de Ciências Sociais da Universidade Federal de Sergipe (UFS), Aracaju - SE, Brasil. E-mail: f.petrarca@hotmail.com

DOI: $10.1590 / 3510403 / 2020$

\section{Introdução}

Este artigo analisa os critérios de seleção profissional e as lógicas de recrutamento das elites médicas sergipanas, baseando-se no exame das propriedades sociais dos seus membros. Tal estudo é um desdobramento de pesquisa mais ampla cujo problema central consistiu na dinâmica de reestruturação das elites dirigentes e suas estratégias de reprodução. ${ }^{1}$ Nessas condições de reconfiguração das elites locais, os títulos universitários - dentre eles o de médico - serviram de suporte para sua consagração em um contexto de transformação do espaço político.

\footnotetext{
*Essa pesquisa foi financiada pelo CNPq e pela Capes, a quem agradecemos por nos permitirem os recursos essenciais para o desenvolvimento e conclusão deste projeto.
}

Artigo recebido em: 29/04/2019

Aprovado em: 29/11/2019
Em termos mais específicos, consideramos - com base no método prosopográfico - a composição social dos dirigentes da medicina em Sergipe, com vistas a demonstrar as mudanças sociográficas, suas variaçóes longitudinais e suas credenciais, tendo como referência empírica aqueles que ocuparam os cargos e as posiçóes mais elevadas nesse espaço profissional e cujas carreiras foram consideradas exitosas pelos seus pares. Esse recorte nos encaminha para dois critérios de construção do objeto. Primeiro, trata-se de um estudo sobre o espaço da medicina em Sergipe, centrando nas condiçóes de carreira realizadas no estado. Segundo, volta-se para aqueles que ocuparam posições de prestígio e/ou comando, gerenciamento e chefia nesse espaço profissional. Isso envolve um exame das carreiras associadas à ocupação de posiçôes no topo das estruturas de autoridade, de classificaçáo e de distribuição de recursos. Nosso marco temporal é a partir da segunda metade do século XIX, momento dos primeiros registros de informaçóes médicas, até 
final do século XX. Uma das principais constataçóes é a de que as mudanças na composição da elite médica e suas dinâmicas de renovação foram observadas, sobretudo, a partir da década de 1940 .

As pesquisas sobre a medicina a partir da análise da sua elite são raras e os estudos, associados em geral a chamada sociologia dos grupos profissionais, deram pouca atenção ao processo de formação dos grupos dominantes no interior do ofício, limitando-se ao exame da formação de um mercado médico (Freidson, 2009), da constituição de comunidades profissionais regidas por códigos e valores (Becker, 1961; Hughes, 1955), dos estágios ou etapas da carreira médica (Hall, 1948) ou, ainda, dos comportamentos e linguagens inerentes aos contextos profissionais cotidianos (Ciccourel, 2002). O exame deste ofício a partir do background social dos seus dirigentes permite compreender os padróes e as condiçóes de ascensão profissional, assim como as estratégias que caracterizam o acesso às posiçōes de maior prestígio nessa atividade.

Essa problemática vem de uma tradição de estudos sobre os grupos dominantes que parte do princípio que nas lutas por classificação e por acesso a certas posiçôes, sobretudo aquelas mais prestigiosas, os agentes comprometem os recursos que acumularam durante seu trajeto social, político e profissional e que resultam de sua origem social, formação escolar e inserção em outras esferas de atividade (Boigeol e Dezalay, 1997; Boltanski, 1982; Bourdieu, 1984, 1989). Contrapondo-se à polarização entre as abordagens "elitista" e "pluralista", ${ }^{1}$ a qual marcou o debate norte-americano nas ciências sociais na década de 1950, tal problemática contribuiu para diversificação dos estudos fazendo emergir objetos empíricos antes ignorados no estudo dos grupos dirigentes. Em função disso, o exame da relação entre estruturas de dominação e espécies de capital se expandiu para análise de diferentes espaços sociais, como intelectual, econômico, jornalístico etc. (Dezalay e Garth, 2000, 2002; Coradini, 1996, 2005, 2008; Lebaron, 2001; Petrarca, 2010; Pinçon e Pinçon-Charlot, 2003; Rieffel, 1984; Sapiro, 2004). Isso pode ser observado, especialmente para o que está em pauta, no caso dos estudos das elites médicas que pela primeira vez passam a ser analisadas a partir do exame dos grupos que ocupam posição dominante no espaço profissional. Destaca-se, nesse aspecto, a análise da relação entre origens sociais, laços familiares e posição dirigente no espaço médico. ${ }^{2}$

Nessa direção, a problemática proposta neste artigo se situa dentro de um esquema conceitual mais amplo que visa abordar os padrôes de recrutamento e de seleção de grupos que ocupam posiçóes elevadas em diferentes esferas sociais e não apenas na esfera política. Parte-se do princípio que o exame exclusivamente das origens sociais e dos recursos políticos e culturais que caracterizam determinado grupo não são suficientes, sendo fundamental examinar as estratégias acionadas no decorrer dos itinerários sociais e profissionais para garantir uma posição de destaque em determinadas esferas. Nesses estudos, uma das linhas de trabalho que tem se consolidado é aquela voltada para as diferentes condiçóes e modalidades de inserção e ascensão profissional.

Uma das principais implicações metodológicas desse tipo de investigação consiste na articulação entre pesquisas históricas e tratamento sociológico, renovando, dessa forma, a temática das elites. Isso se traduziu no exame das trajetórias e no uso do método prosopográfico ou das biografias coletivas, como também é denominado, como instrumento de coleta de dados que permite, a partir de um grande número de membros de uma mesma população, previamente definida, verificar as características particulares, o perfil sociográfico e as variações no tempo. Constituindo-se, portanto, como ferramenta de estudo do passado, ele contribui ainda para formulação de diretrizes centrais da pesquisa (Barickman e Love, 2006; Charle, 2006; Heinz, 2006; Roy e Saint-Pierre, 2006).

A mobilização desse método, neste trabalho, permitiu estabelecer um perfil social tanto do grupo familiar, quanto da formação escolar e acadêmica dos médicos, bem como dos seus investimentos em outras esferas sociais, como a política, por exemplo. Tal tratamento contribuiu para dar visibilidade, ainda, para o peso que essas diferentes esferas têm para compreensão das condiçóes sociais da ascensão na medicina. $\mathrm{O}$ seu uso envolveu a reflexão de pelo menos três momentos essenciais.

Primeiro, estabelecer uma lista daqueles que comportam a população definida como alvo do 
estudo. No caso desta pesquisa partimos daqueles que ocuparam os postos mais consagrados no interior da medicina, o que envolveu um conjunto de critérios para definir a elite médica. De um lado, tomamos como condição a ocupação de cargos de direção. De outro, consideramos a definição da própria categoria médica para demarcação de sua "elite" e - na falta de uma instituição que nos fornecesse dados para tal - recorremos ao Dicionário médico biográfico (Santana, 2009) como uma das principais publicaçóes regionais de autoconsagração do grupo profissional. Esse dicionário reúne tanto os médicos sergipanos por nascimento quanto aqueles que atuaram no estado e que se destacaram. Para este estudo, como já explicitado, consideramos apenas os que fizeram carreira no estado. Nosso banco de dados permitiu analisar uma população de 428 médicos no período de 1840 até as últimas décadas do século XX.

Segundo, é preciso partir para a documentação biográfica e estabelecer pequenos verbetes para cada indivíduo, considerando: origens sociais; formação escolar e acadêmica e carreira profissional. Levamos em conta, para esta pesquisa, além do dicionário já citado, outras fontes para ampliação dos dados biográficos, tais como: biografias, perfil publicado em revistas, documento de jornais, entrevistas publicadas. A partir de tais verbetes codificamos 54 variáveis, as quais nos permitiram medir: origem geográfica, local da formação profissional, profissão dos pais e grau de escolaridade, vinculação com a política, relação com a medicina, como postos ocupados, e inserção em outras esferas, como jornalística e religiosa.

E, o terceiro, identificar tanto os pontos comuns, as regularidades e particularidades, quanto as variaçóes nas propriedades e atributos dessa coletividade. Nesse aspecto o uso desse método nos permitiu considerar as reconfiguraçóes das elites médicas locais. Para tal se tornou fundamental a articulação entre as informações biográficas, com dados sobre a história social dos grupos, o contexto e as lógicas situacionais a partir das quais se situam os agentes investigados. Isso permitiu um controle maior sobre a confiabilidade dos dados biográficos.

A relevância deste estudo sobre a dinâmica de formação de grupos dirigentes no interior da medicina decorre, de um lado, da dimensão teórica e metodológica e dos desafios de apreensão relacional entre a ascensão profissional e as condições e estrutura de capital que tornam possível o investimento na medicina. De outro lado, decorre da dimensão empírica, uma vez que a profissão médica tem sido considerada, especialmente pela literatura especializada em universos profissionais, como a atividade que mais conquistou poder e privilégio (Freidson, 2009). Ao longo da sua história a atividade tomou para si o monopólio da cura e reivindicou, com sucesso, o poder de definir o que é doença. Além disso, teve papel significativo na definição das políticas de saúde, ocupando posiçóes de destaque e de comando na constituição da saúde pública. Com um projeto profissional bem-sucedido, com notável aliança com o Estado e com as elites políticas, a medicina negociou o exercício profissional e conquistou prestígio e status. É ainda a partir da relação entre a dimensão teórica e a dimensão empírica que o estudo de caso da medicina em Sergipe pode servir de inspiração para análise mais profunda da relação entre recrutamento da elite médica e os mecanismos de renovação das elites regionais. Por se tratar de uma elite política extremamente fragmentada, circunscrita e situada em um estado periférico e estruturada a partir de uma forte concorrência, a distinção e hierarquização entre os grupos dependeu da mobilização de recursos sociais cada vez mais diversificados. É nessa direção que os títulos acadêmicos e o investimento em espaços profissionais constituíram os movimentos de recomposição dessas elites, sobretudo em momentos de crises políticas e econômicas, desempenhando um papel fundamental na renovação dos dirigentes regionais. Assim, a disputa pela ocupação de cargos entre as fraçóes das elites políticas locais passou a depender, cada vez mais, dos bacharéis aptos a mobilizar não só seus saberes profissionais, mas também suas redes de relações para ocupação de cargos municipais, estaduais e federais.

Para dar conta das questóes e desafios aqui propostos, este artigo está divido em três partes. $\mathrm{Na}$ primeira trata-se de demonstrar a formação e composição social desse grupo profissional e sua variação longitudinal tendo como base os dados sociográficos. Na segunda, o perfil de carreira dessa elite examinada, tendo em vista os cargos ocupados, 
formação e entrada no mercado de trabalho. E por fim adentrar, a partir dos indicadores prosopográficos, nos padróes de recrutamento e modalidades de investimento na medicina tomando como ponto de reflexão a relação entre família, política e estratégias de reconfiguração da elite médica local. Este último tópico permite combinar os dados prosopográficos com uma análise mais detalhada acerca das dinâmicas das trajetórias individuais. Além disso, é a partir dele que se pode observar como se combinam os investimentos em postos dirigentes em instituiçóes médicas e os mecanismos de recomposição das elites regionais.

\section{Formação e composição social da "alta" medicina}

Um dos principais desafios no exame dos atributos e características sociais da dos grupos dirigentes é o de estabelecer certos parâmetros que permitam identificar as transformaçóes e as reconfigurações em jogo. No que diz respeito às particularidades mais gerais da elite médica, o banco de dados produzido nos permitiu identificar que a partir da década de 1940 se intensifica o processo de institucionalização e profissionalização da medicina em Sergipe. Nesse período é possível observar um conjunto de transformaçóes, tais como: o surgimento de cursos de formação e das faculdades de medicina, cuja consequência foi a emergência de um saber médico produzido a partir do estado; um maior investimento dos médicos em entidades de representação de classe e em setores de atividades vinculados à medicina; um menor investimento na esfera política e o aparecimento da atividade de clínica médica como principal forma de vínculo profissional, em detrimento de outras observadas no passado, como ocupação de postos políticos e investimento numa carreira política a partir da medicina. É com base nesses elementos que se forma um modelo de organização do trabalho médico mais voltado à clínica e à intervençáo individual a partir de um mercado privado. Tal situação contribuiu para oferecer novas oportunidades aos profissionais.

Tais consideraçóes gerais nos permitiram definir alguns períodos, seguindo os anos de formação universitária, para melhor compreender as variaçóes e as transformaçóes dessa elite. Um primeiro período corresponde aos médicos nascidos durante o século XIX, formados entre 1840 e 1889 e que seguiram as atividades econômicas familiares com fortes investimentos políticos. O exercício da medicina para esse grupo, quando ocorria, limitava-se, no geral, a dois anos. O segundo representa aqueles que nasceram desde a segunda metade do século XIX (1860) até as primeiras décadas do século XX (1920), formados no período que se inicia com a República até a década de 1940 e cujas atividades foram marcadas pela intensa atividade política, com um incipiente investimento na clínica médica. Essa geração representa aqueles que fizeram um investimento duplo, no espaço da política e na formação de um mercado de serviços médicos. O terceiro grupo corresponde aos nascidos de 1920 até a década de 1960, formados entre 1941 e 1980, cujo exercício da medicina se caracteriza pelo intenso investimento clínico, com progressivo declínio do investimento político. Essa geração corresponde a um marco nas mudanças associadas ao perfil da elite médica. Por fim, aqueles cujo nascimento é mais recente, datando o final dos anos 1960 até os anos de 1980, formados entre 1981 e anos 2000.

Dentro dessa caracterização geral foi possível identificar, conforma mostra o Quadro 1, com relação ao sexo, uma elite majoritariamente masculina, composta

\section{QUADRO 1
PERÍODO DE FORMAÇÃO POR SEXO}

\begin{tabular}{llcccccc}
\hline & & \multicolumn{4}{c}{ Período de Formaçáo } & \multirow{2}{*}{ Total } \\
\cline { 2 - 7 } & & $\mathbf{1 8 4 0 - 1 8 8 9}$ & $\mathbf{1 8 9 0 - 1 9 4 0}$ & $\mathbf{1 9 4 1 - 1 9 8 0}$ & $\mathbf{1 9 8 1 - 2 0 0 0}$ & \\
\hline \multirow{2}{*}{ Sexo } & Masculino & 112 & 111 & 156 & 23 & 402 \\
\cline { 2 - 7 } & Feminino & 0 & 3 & 17 & 6 & 26 \\
\hline \multirow{2}{*}{ Total } & & 112 & 114 & 173 & 29 & 428 \\
\hline
\end{tabular}

Fonte: Banco de dados da autora 
de $93,9 \%$ de homens e $6,1 \%$ de mulheres. Como se pode observar, o fenômeno da "feminizaçâo" da medicina a partir de sua elite não aconteceu em Sergipe, pois, apesar de haver um crescimento no número de mulheres a partir dos anos 1940, o banco nos mostra que isso foi circunstancial e consideravelmente baixo. De 1940 até a década de 2000 apenas 23 mulheres se destacaram. A inserção das mulheres no espaço da medicina no Brasil já foi ressaltada em outro trabalho (Carneiro e Gouveia, 2004) que apontou um aumento expressivo na formação de mulheres nessa área, que passaram a corresponder a $30,2 \%$ do universo, em contraposição a $69,8 \%$ de homens.

Como nos mostra o quadro acima, as condiçóes para as mulheres ascenderem aos postos dominantes na medicina, tanto no que diz respeito às condiçôes de comando quanto ao prestígio entre os pares, são baixas quando comparadas as dos homens. Esse tipo de constatação tem sido observado em outros universos profissionais e constitui o fenômeno denominado "teto de vidro". Trata-se de uma metáfora para compreender a barreira invisível que impede as mulheres de chegar aos cargos de direção, conduzindo a uma desigualdade de gênero no mercado de trabalho (Ramalho e Santana, 2010). Assim, mesmo tendo experimentado um crescimento no mercado profissional médico, as mulheres esbarram nos constrangimentos de acesso aos postos de comando.

A análise da origem geográfica, a partir do local de nascimento, nos permitiu identificar as regióes que mais contribuíram e que estavam mais predispostas a formação da liderança médica. A partir dela podemos perceber que 72,9\% dos médicos são originários de Sergipe. Do conjunto dos originários do estado, $75,3 \%$ são do interior e $24,6 \%$ da capital, Aracaju. Nesse grupo também há espaço para médicos nascidos fora do estado, uma vez que $20 \%$ são originários de outros estados do Nordeste; $2,8 \%$ do Sudeste, $1,2 \%$ do exterior e $0,9 \%$ do Norte e $0,2 \%$ do Centro-Oeste, para os demais não há registros. Tomados em conjunto, esses dados podem nos mostrar que se trata, portanto, de um grupo predominantemente regional, localizado no estado, e com raízes fortes no interior.

Entretanto, esse dado precisa ser relacionado com duas outras informaçóes: primeiro, há uma mudança significativa, ao longo do período estudado, no local de origem dos médicos, com crescente valorização daqueles que se deslocavam não mais a partir do interior de Sergipe, mas da capital Aracaju e de outras regiôes do país, sobretudo dos estados do Nordeste. Segundo, há uma transformação econômica no estado, que alterou as formas de recrutamento das elites médicas.

As geraçōes que se formaram no século XIX são predominantemente do interior de Sergipe, da chamada "região dos engenhos", que incluía as cidades de Divina Pastora, Maruim, Riachuelo, Rosário do Catete, Santa Luzia da Itanhy, dentre outras, e dos centros econômicos, políticos e culturais do período, como a cidade de Laranjeiras e Estância que se tornaram palco do nascimento da imprensa e do movimento republicano no estado. ${ }^{3}$ Conforme

\section{QUADRO 2}

\section{ORIGEM GEOGRÁFICA DA ELITE MÉDICA POR PERÍODOS}

\begin{tabular}{|c|c|c|c|c|c|c|}
\hline & & \multicolumn{4}{|c|}{ Período de Formaçáo } & \multirow{2}{*}{ Total } \\
\hline & & $1840-1889$ & $1890-1940$ & 1941-1980 & $1981-2000$ & \\
\hline \multirow{8}{*}{ Regiấo de Nascimento } & Aracaju & 1 & 16 & 46 & 15 & 78 \\
\hline & Interior de Sergipe & 101 & 66 & 59 & 9 & 235 \\
\hline & Nordeste & 7 & 25 & 53 & 1 & 86 \\
\hline & Norte & 0 & 2 & 2 & 0 & 4 \\
\hline & Sudeste & 0 & 2 & 6 & 4 & 12 \\
\hline & Centro Oeste & 0 & 0 & 1 & 0 & 1 \\
\hline & Exterior & 1 & 0 & 4 & 0 & 5 \\
\hline & Não Informa & 2 & 3 & 2 & 0 & 7 \\
\hline Total & & 112 & 114 & 173 & 29 & 428 \\
\hline
\end{tabular}

Fonte: Banco de dados da autora 
o Quadro 2, é a partir da década de 1940 que se observam movimentos mais bruscos de diversificação das origens geográficas, com diminuição significativa dos nascidos no interior do estado e aumento dos oriundos da capital e de outras cidades do Nordeste.

É nesse período, ainda, que ocorre uma diferenciação econômica no estado, com o progressivo declínio e decadência da sociedade rural litorânea e a emergência das fábricas de tecido, da indústria, do comércio e o crescimento da máquina estatal na capital (Dantas, 2004). Tais condiçôes contribuíram para colocar a cidade de Aracaju, paulatinamente, como o centro produtivo do estado e não mais seu interior. Essas transformaçóes modificaram a atividade econômica dos pais dos médicos, como se observará adiante, alternando as origens sociais desse grupo e conduzindo à emergência de comerciantes, profissionais liberais e funcionários do Estado. Como o processo de urbanização do estado é recente, uma vez que até a década de 1960 este era eminentemente agrário, as elites profissionais se originavam fundamentalmente do interior. Nessas condiçóes, as regióes econômica e politicamente mais ativas estavam mais propensas à formação de médicos dirigentes.

No que diz respeito à posição social de origem, partimos da profissão do pai como um dos principais indicadores. Apesar da fragilidade desse dado, tendo em vista que conseguimos reunir essas informaçóes para 166 casos, do conjunto de 428, é possível observar que os médicos eram recrutados dentro das fraçôes mais elevadas da elite política sergipana. Do conjunto, $34,3 \%$ dos médicos eram filhos de militares, $15 \%$ eram filhos de médicos e $8,4 \%$ eram filhos de políticos. Militares, médicos e políticos corresponderam às principais profissóes que se destacaram no banco de dados até meados dos anos 1940. É interessante notar também que até meados dos anos 1930 eram os militares que controlavam o setor de serviços médicos, como diretores de hospitais, institutos e clínicas. Como se trata de um amplo banco de dados, as informaçóes sobre origens sociais só fazem sentido quando associadas a um determinado período histórico, a um recorte temporal mais preciso. Assim, podemos perceber que até meados do século XX a grande maioria descendia de pais militares. Nesse contexto, proprietários de engenho e usineiros recebiam também títulos e honrarias militares, o que os tornava ao mesmo tempo, fazendeiros e militares. Uma destas designaçôes era a de "coronel", que no nosso banco classificamos como militar, e cujo título representava uma posição política associada à Guarda Nacional. Nessas condiçóes, o "coronel" era, portanto, o fazendeiro que devido a sua posição econômica adquiriu autoridade militar e estava apto a desempenhar funçôes de segurança do território nacional. Assim ele se tornava um chefe político local. Com a extinção da Guarda Nacional os coronéis continuaram se atribuindo essa denominação, que passou a representar um tipo de poder local baseado na barganha entre governo e oligarquias locais, das quais eram os principais representantes. ${ }^{4}$

Como lidamos com informaçóes produzidas por outras fontes (dicionário biográfico, homenagens, obras biográficas), o registro "coronel" aparece de forma variada nas fontes biográficas nas quais nos baseamos, ora caracterizado como militar, ora como fazendeiro, ora como coronel. Nesse contexto, esse registro dificultou a caracterização da atividade profissional dos pais dos médicos. Em função disso, optamos pelo registro genérico "militar".

Como mostra o Quadro 3, essas origens se diversificaram a partir de meados dos anos 1940 com o desenvolvimento de outras atividades associadas aos ofícios liberais (como direito, engenharia, medicina, odontologia), ao magistério e também com o crescimento do número de pais com ofícios que não dependiam da formação universitária, como retratista, pequeno comerciante, pequenos funcionários públicos (funcionário dos correios, do porto, entre outras). Tal diversificação está associada a uma mudança na atividade produtiva a partir da capital, com o aumento do comércio, dos ofícios liberais e a ampliação do funcionamento da máquina estatal.

No que diz respeito ao local de formação profissional, os dados os dados expostos no Quadro 4 demonstram que, por tratar-se de uma elite periférica, ${ }^{5}$ a formação acadêmica se volta para os estados dominantes do Sudeste, como Rio de Janeiro e São Paulo, ou para aqueles que adquiriam importância na formação médica, como é o caso da Bahia, esta última com $61,7 \%$ do nosso universo. 
QUADRO 3

ORIGENS SOCIAIS POR PERÍODOS

\begin{tabular}{|c|c|c|c|c|c|c|}
\hline & & \multicolumn{4}{|c|}{ Período de Formaçáo } & \multirow{2}{*}{ Tota } \\
\hline & & 1840-1889 & $1890-1940$ & 1941-1980 & $1981-2000$ & \\
\hline \multirow{11}{*}{$\begin{array}{l}\text { Profissão } \\
\text { do Pai }\end{array}$} & Militar & 36 & 17 & 3 & 1 & 57 \\
\hline & Médico & 9 & 6 & 6 & 4 & 25 \\
\hline & Profissional liberal & 1 & 3 & 5 & 3 & 12 \\
\hline & Politico & 6 & 1 & 4 & 3 & 14 \\
\hline & Padre & 3 & 0 & 0 & 0 & 3 \\
\hline & Pecuarista/fazendeiro/industrial & 1 & 6 & 1 & 0 & 8 \\
\hline & Comerciante/retratista/feirante & 2 & 2 & 9 & 2 & 15 \\
\hline & Professor & 1 & 1 & 2 & 0 & 4 \\
\hline & Magistrado & 5 & 4 & 2 & 0 & 11 \\
\hline & Pequenos funcionários públicos e privados & 0 & 3 & 10 & 3 & 16 \\
\hline & Não informado & 0 & 0 & 0 & 1 & 1 \\
\hline Total & & 64 & 43 & 42 & 17 & 166 \\
\hline
\end{tabular}

Fonte: Banco de dados da autora

QUADRO 4

LOCAL DE FORMAÇÃO POR PERÍODOS

\begin{tabular}{|c|c|c|c|c|c|c|}
\hline & & \multicolumn{4}{|c|}{ Período de Formaçáo } & \multirow{2}{*}{ Total } \\
\hline & & 1840-1889 & $1890-1940$ & $1941-1980$ & 1981-2000 & \\
\hline \multirow{6}{*}{ Local de formação } & Bahia & 93 & 85 & 83 & 3 & 264 \\
\hline & Sudeste & 14 & 25 & 13 & 2 & 54 \\
\hline & Nordeste & 0 & 3 & 30 & 1 & 34 \\
\hline & Demais Regióes & 0 & 1 & 2 & 0 & 3 \\
\hline & Exterior & 5 & 0 & 0 & 0 & 5 \\
\hline & Sergipe & 0 & 0 & 45 & 23 & 68 \\
\hline Total & & 112 & 114 & 173 & 29 & 428 \\
\hline
\end{tabular}

Fonte: Banco de dados da autora

Até 1940 a formação desta elite era bastante homogênea, com forte concentração na Faculdade de Medicina da Bahia e do Rio de Janeiro. A partir desse período observamos uma concorrência maior com outras faculdades distribuídas nas regiōes Sudeste e Nordeste, além do crescente investimento na Faculdade de Medicina de Sergipe. Isso está associado à expansão do ensino médico que acontece no decorrer do século $\mathrm{XX}$, com a criação das faculdades de medicina de São Paulo, em 1913, de Pernambuco, em 1920 e do Paraná em 1922. Até o final do século XIX apenas três faculdades formavam médicos em todo o país (Rio de Janeiro, Bahia e Rio Grande do Sul). O curso de medicina em Sergipe só irá se consolidar na década de 1960, mas é, sobretudo, para os formados pós-1980 que a faculdade de medicina sergipana se torna mais atraente, consolidando uma elite treinada localmente. Nesse grupo pode se observar que $80 \%$ dos profissionais são formados em Sergipe, em oposição à geração anterior, com $26 \%$.

Além dos dados quantitativos, essa variável permite compreender o contexto socializador dessa elite e, em certa medida, suas conexóes locais e interestaduais, uma vez que as faculdades de medicina funcionam não só como espaços de treinamento, mas também como espaço de formação de redes de relaçóes essenciais para o exercício do ofício. Nesse sentido, a própria característica da vida acadêmica, em diferentes períodos, pode trazer indícios importantes sobre a composição social dessa elite profissional. 
Durante todo o período imperial e parte do republicano, a vida acadêmica voltava-se, preferencialmente, para vida política, não só por meio dos saberes produzidos que permitiam conectar a importância dos bacharéis para a política como também por meio das redes estabelecidas no interior das faculdades e que contribuíam para introdução numa carreira política. Com a República, a contribuição dos médicos na consolidação do novo regime se intensificou, sobretudo por meio do avanço das propostas sanitaristas e a definição da saúde pública. O novo regime consolidou órgãos específicos na saúde pública, como a criação de serviços sanitários em vários estados, instituto de vacinas, laboratórios, ampliando os postos de trabalho. As discussóes científicas conduziam os médicos a colocar seus ofícios a serviço da política e da formação do Estado, ocupando espaços nos hospitais e nas delegacias e comissóes de higiene. Nessa direção, a Faculdade de Medicina da Bahia teve um papel de destaque não só nas discussóes sobre a expansão da febre amarela, por exemplo, e o papel do Estado no controle da epidemia, mas também como centro intelectual e irradiador de debates durante todo o século XIX e boa parte do século XX (Edler, 1998, 2002). Além disso, a Faculdade de Medicina da Bahia absorvia os herdeiros da elite agrária do período constituindo-se como celeiro de pessoal político.

Nesse contexto, estudar fora dos limites do município e do estado contribuiu para formação de redes de relaçóes próprias e para as possibilidades de conexão com suas bases regionais. Até meados do século $\mathrm{XX}$, antes da consolidação de um mercado privado de serviços médicos, essa necessidade se tornava um trunfo político para as elites, pois o filho bacharel ampliava a rede política da família cristalizando vínculos que transcendiam as alianças locais (Lewin, 1993). Contudo, no curso do século XX, sobretudo após os anos 1940, com a diversificação das origens sociais, a necessidade de estudar fora do estado como estratégia para expansão das redes familiares passa a ser substituída pelo investimento intenso num mercado de serviços interno.

A concentração, portanto, da formação na Faculdade de Medicina da Bahia contribuiu, de um lado, para reforçar o processo de aprendizagem das habilidades para o ofício da política, já que a mesma ocupou um lugar de destaque nos debates políticos, contribuindo para unificação ideológica da elite médica, sobretudo para as gerações anteriores a década de 1940. Por outro lado, colaborou para intensificar as conexóes entre as elites locais e as elites regionais.

As três variáveis aqui apresentadas, a saber: origem geográfica, origem social e local de formação acadêmica, nos permitem compreender não só como eram recrutados os médicos, mas também a combinação dos processos de transformação no recrutamento médico com a renovação das elites regionais. Como se pode observar, o recrutamento ocorria, fundamentalmente, dentro das fraçóes das famílias dirigentes, com ênfase nos proprietários de engenho que eram também chefes políticos locais. Contudo, as transformaçóes econômicas do estado, com o notável declínio da produção de açúcar, provocaram mudanças no recrutamento dessa elite profissional. Primeiro, uma discreta modificação nas origens sociais, dado o avanço da máquina estatal a partir da capital e não mais do interior rural e agrário. Segundo, como parte das estratégias de sobrevivência social, a própria elite açucareira passa a diversificar sua atuação econômica investindo na expansão das fábricas, no comércio e ocupando postos do Estado (hospitais, delegacias de saúde, comissóes de higiene etc.). Nessa direção, o investimento, sobretudo na formação acadêmica dos filhos, tornava-se uma estratégia não só para ampliar as redes de relaçóes políticas, as quais deixam de ser locais para se tornarem regionais, mas também para expandir a ocupação de cargos estaduais e federais, reconfigurando, portanto, a elite regional. Com o avanço da República se redefine uma elite cujo caráter não será apenas municipal e local, mas regional. ${ }^{6}$

Tais condiçóes caracterizaram uma elite bastante homogênea, uma vez que era recrutada das fraçóes dominantes, treinada e formada pelas mesmas faculdades e voltada para uma medicina pública, capaz de permitir transformar os problemas individuais em problemas de saúde pública que exigiam medidas políticas. Uma das consequências foi o investimento na vida política, sobretudo a partir dos seus municípios de origem.

Além disso, o exame das homenagens recebidas também constituiu um elemento importante da caracterização desses médicos e seus processos de 


\begin{tabular}{|c|c|c|c|c|c|c|}
\hline \multicolumn{7}{|c|}{$\begin{array}{c}\text { QUADRO } 5 \\
\text { HOMENAGENS POR PERÍODOS }\end{array}$} \\
\hline & & \multicolumn{4}{|c|}{$\begin{array}{ll}\text { Período de Formaçáo } \\
\end{array}$} & \multirow{2}{*}{ Total } \\
\hline & & 1840-1889 & $1890-1940$ & $1941-1980$ & 1981-2000 & \\
\hline \multirow{2}{*}{ Homenagens } & Uma instituição & 20 & 20 & 20 & 2 & 62 \\
\hline & Mais de uma & 2 & 8 & 3 & 1 & 14 \\
\hline Total & & 22 & 28 & 23 & 3 & 76 \\
\hline
\end{tabular}

transformação. Com base nos dados expostos no Quadro 5, foi possível perceber que 17,7\% dos médicos receberam homenagens de diferentes tipos de instituição, em contraposição aos $82,3 \%$ que náo receberam. Do conjunto daqueles que foram homenageados: 52,6\% receberam homenagens de instituiçóes profissionais (associaçóes, entidades e conselhos de defesa da categoria médica); 50\% de instituições políticas (partidos, governos e órgãos estatais); 9,2\% de instituiçóes literárias (academia de letras e entidades afins); 5,2\% de instituiçóes educacionais (escolas, bibliotecas, universidades); $3,9 \%$ instituiçóes religiosas (igrejas, congregações) e 2,6\% de instituiçóes internacionais. Além disso, distinguimos que desse universo $18,4 \%$ recebeu homenagem de mais de uma instituição.

Tratada no conjunto, essa variável pode transparecer pouca relevância estatística. Contudo, como estamos lidando com um banco extenso em longo período de tempo, é fundamental que se considerem os contextos e os períodos. Nesse sentido, a relevância deste dado consiste, por um lado, na relação desta variável (homenagem) com os períodos de formação e, por outro lado, por permitir observar as instituições que consagraram o ofício profissional. A análise dos períodos de formação permitiu identificar diferentes geraçôes de médicos que se consagraram pelas homenagens recebidas. As geraçóes que receberam mais homenagens foram as do final do século XIX até a década de 1940 e as geraçóes de 1941 até 1980 , correspondendo a $67,1 \%$ do conjunto dos homenageados. Análise mais detalhada permitiu demonstrar que é para estas últimas que se destaca a presença de mais de uma instituição que concedeu homenagem. Portanto, é para as elites anteriores à década de 1980 que as homenagens aparecem como elemento de distinção, permitindo a geraçôes de médicos consagrarem-se pelo acúmulo de homenagens recebidas.
Com relação aos organismos que se destacam ao longo do período estudado, os principais espaços de consagração médica são as instituiçốes profissionais e as políticas. A relevância das instituições políticas como espaço de consagração adquire importância até os anos 1960, momento em que apresenta significativa queda. Logo, as instituiçóes profissionais destacam-se entre as décadas de 1920 e 1960; a partir desse período também elas deixam de ter importância.

A configuração dessas homenagens está relacionada a duas questôes centrais. Primeiro, que no século XIX o ofício médico privado não era a ocupação principal, mas um ofício secundário. Era para a medicina pública e para a vida política que esses profissionais se voltavam. As gerações do final do século XIX e do início do século XX coincidem com as elites sociais, econômicas e políticas. Segundo, é a partir de 1930 que a medicina clínica, voltada para um mercado privado, começa a aparecer, em Sergipe, como um ofício do qual se podia viver. Ela ganha institucionalização de fato a partir da década de 1940, mas esse processo tem início nos anos 1920. O aparecimento das instituições de representação de classe ocupou um lugar central no reconhecimento profissional, nesse contexto, contribuindo para promover uma nova concorrência nas formas de consagração médica, além dos espaços tradicionais da política (partidos, cargos estatais). Nesse sentido, a elite que emergiu entre as décadas de 1940 e 1980 merece tratamento especial já que se caracteriza como um divisor de águas na institucionalização da medicina. Por esse motivo, essa geração tende a manter as homenagens que caracterizam o período anterior, promovidas principalmente por instituiçóes políticas, e a atualizar seu reconhecimento a partir das homenagens concedidas por instituições médicas. Assim ela se torna a geração que se consagra pelo acúmulo de homenagens. 


\section{Perfil de carreira e condiçáo de elite}

Para traçar o perfil de carreira da população estudada partimos de um conjunto de variáveis e medidas, tais como: a idade em que se formaram e que começaram a exercer o ofício médico, as especialidades exercidas, os tipos de cargos ocupados e as diferentes formas de vinculação com a esfera política, medida, sobretudo pela participação em partidos políticos e pela ocupação de cargos políticos (secretarias de estado, chefia de hospitais públicos, dentre outras).

A idade média com a qual os membros da elite concluíram suas graduaçôes é correspondente à média de idade de entrada no mercado de trabalho, o que indica um ingresso instantâneo na ocupação de postos. A primeira é de 27 anos e a segunda média é de 28 anos. Tal fato está associado à própria dinâmica do mercado disponível e dos postos que podem ser ocupados por médicos. De um lado, o mercado está aberto para os recém-chegados, contribuindo para uma entrada acessível na profissão e evitando as dificuldades que os recém-formados enfrentam no acesso ao mundo dos empregos. De outro lado, a dinâmica desse mercado garante a permanência daqueles já estabelecidos e fixados no ofício, conduzindo a um longo exercício profissional e a um baixo abandono da carreira. Segundo Machado (1997) e Carneiro e Gouveia (2004) o tempo dos registros profissionais varia na faixa dos 50 anos e $98 \%$ dos médicos estão em atividade nos últimos dez anos. Trata-se de um mercado que praticamente desconhece o desemprego e cuja lógica garante aos recém-formados acesso rápido aos postos e permite aos mais antigos postergar a aposentaria pelo maior tempo possível.

No que diz respeito à atuação na medicina, até a década de 1940 se destacavam clínicos, ginecologistas e obstetras e cirurgióes. É somente após a década de 1950 que as demais especialidades começam a aparecer (pneumologia, pediatria, oftalmologia, dermatologia). A expansão dessas especialidades está associada tanto à diversificação do mercado médico, quanto à criação do programa de residência médica como centro de especialidade. Atualmente, o Conselho Federal de Medicina reconhece 52 especialidades desenvolvidas por meio da realização da residência que, apesar de ter sido criada na década de 1940, no Rio de Janeiro e em São Paulo, ganha impulso somente a partir da década de 1970 (Machado, 1997). Até esse momento os médicos se autoatribuíam especialidades de acordo com o investimento que faziam no mercado de serviços médicos e com a prática profissional exercida nessa área.

Quanto ao local de inserção no mercado, 65,4\% dos médicos começaram suas carreiras profissionais em Sergipe, 16,6\%, em outras capitais, em especial Salvador e Rio de Janeiro, estes últimos por serem espaços de formação privilegiados até meados da década de 1960. Além disso, há correlação entre a região de origem e a regiáo de investimento profissional, pois o início das carreiras dos médicos analisados ocorre nas regiôes de origem. Outro dado importante é a relação entre capital e interior. Apesar das capitais aparecerem com mais freqüência para o início da carreira médica $(49,8 \%)$, o interior é bastante atrativo, representando $43,4 \%$ dos locais de entrada no mercado.

Conforme o Quadro 6, apesar de ter ocorrido um acréscimo no investimento profissional a partir da capital, até 1940 o interior do estado de Sergipe, e o interior do país de modo geral, apresentava-se como espaço de importante recepção para o início da carreira médica. É, sobretudo, a partir da década de 1940 que a capital Aracaju passa a atrair mais os médicos recém-formados. Isso está associado a alguns fatores. Primeiro, até a década de 1940 a medicina estava mais voltada para formação de quadros para a política, como destacado nos tópicos anteriores, seja na ocupaçáo de cargos eletivos (deputados, senadores, governadores), seja na ocupação de cargos de Estado (secretários de saúde, delegados de higiene). Nesse sentido, o interior se tornava mais importante porque a partir dele era possível construir uma base de apoio fundamental para uma carreira na política. Segundo, é a partir da década de 1940 que se desenvolve o que Machado (1997) chama de "vocação urbana" da profissão. Tomando como referência esses dados, podemos associar a formaçáo de um mercado privado de serviços médicos à urbanização da medicina. $\mathrm{Na}$ medida em que o mercado se consolida os médicos tendem a se fixar mais onde esse mercado é mais estruturado, que é justamente onde se encontram as instituiçóes de representação profissional e os espaços de formação, como hospitais escola, universidade e faculdades. 


\section{QUADRO 6 \\ LOCAL DE INVESTIMENTO NA CARREIRA MÉDICA POR PERÍODOS}

\begin{tabular}{|c|c|c|c|c|c|c|}
\hline & & \multicolumn{4}{|c|}{ Período de Formaçáo } & \multirow{2}{*}{ Total } \\
\hline & & $1840-1889$ & $1890-1940$ & 1941-1980 & $1981-2000$ & \\
\hline \multirow{7}{*}{ Cidade } & Aracaju & 13 & 45 & 68 & 16 & 142 \\
\hline & Interior de Sergipe & 56 & 36 & 39 & 7 & 138 \\
\hline & Salvador & 3 & 4 & 12 & 1 & 20 \\
\hline & Interior da Bahia & 3 & 3 & 0 & 0 & 6 \\
\hline & Outras capitais & 11 & 10 & 30 & 0 & 51 \\
\hline & Interior do País & 17 & 10 & 13 & 2 & 42 \\
\hline & Não informa & 9 & 6 & 11 & 3 & 29 \\
\hline Total & & 112 & 114 & 172 & 25 & 428 \\
\hline
\end{tabular}

Fonte: Banco de dados da autora

Um conjunto de outras variáveis, como cargos de direção ocupados e a respectiva área, permitiu compor o quadro do perfil dessa elite profissional. Do conjunto do universo analisado, só há registro desse dado para 59,1\% dos médicos. Os espaços de ocupação de tais cargos são diversificados e vão desde hospitais e casas de saúde, a órgãos não relacionados à temática da saúde, entidades profissionais e mais de um desses espaços. O que se percebeu é que, conforme demonstra o Quadro 7, 53,3\% daqueles que ocuparam cargos de direção exerceram-no em mais de um desses espaços.

Vale ressaltar que os órgãos estatais se destacam nesse sentido, sobretudo hospitais públicos e secretarias de saúde. A participação na direção de hospitais, casas de saúde e entidades de representação profissional se destaca após as décadas de 1940 e 1950 . É nesse período que se observa um aumento significativo da participação dos médicos em vários espaços de direção. Trata-se de um dado com crescimento até a década de 1980 .

A ocupação de cargos públicos marca a geração do século XIX e início do século XX. Para essa geração o investimento nos altos cargos do Estado constituía-se como uma estratégia de sobrevivência do seu grupo de origem. Filhos da aristocracia agrária em decadência, esses bacharéis viram no emprego público não uma etapa passageira ou um hobby, como mostra Carvalho (2007) sobre a elite política, mas uma forma de sobreviver enquanto elite. Como as oportunidades de trabalho no mercado médico privado eram praticamente inexistentes nesse contexto, os cargos públicos constituíam-se como espaços importantes de investimento numa carreira política, garantindo a sobrevivência do grupo e aumentando sua legitimidade. Contudo, é a geração de 1941-1980 que acumula posições em múltiplos espaços, pois esse é o contexto de forte expansão da medicina pública, cuja característica era o investimento numa carreira política e médica ao mesmo tempo, e o momento em que se observa a intensa atuação das entidades de representação profissional.

Podemos dizer que o que define e caracteriza essa elite, num primeiro momento, é a vinculação e o pertencimento a uma oligarquia rural e a ocupação de cargos na burocracia pública e conseqüente investimento na política eletiva, como deputados, senadores, governadores. Essa é a geração do século XIX que acumulava um patrimônio pessoal e familiar que conduzia a vida política. Portanto, eram membros das fraçôes mais elevadas da elite política e do corpo político legislativo. Num segundo momento, está assentada no duplo investimento e na combinaçáo entre vida profissional, ocupação de postos nas associaçóes e espaços de representação e carreira política, esta última com atribuições eletivas e administrativas. Essa é a geração do final do século XIX e das primeiras décadas do XX, que se destaca pelo acúmulo de múltiplas funções e pelo intenso trânsito entre um recém-criado espaço de representação profissional e a política. É somente após os anos 1940/1950 que temos uma dedicaçáo maior ao mercado de serviços médicos e um afastamento progressivo dos cargos políticos. Com o crescimento da competição 


\section{QUADRO 7 \\ CARGOS DE DIREÇÃO POR PERÍODOS}

\begin{tabular}{lllccccc}
\hline & & \multicolumn{4}{c}{ Período de Formaçáo } & \multirow{2}{*}{ Total } \\
\cline { 3 - 7 } & & $\mathbf{1 8 4 0 - 1 8 8 9}$ & $\mathbf{1 8 9 0 - 1 9 4 0}$ & $\mathbf{1 9 4 1 - 1 9 8 0}$ & $\mathbf{1 9 8 1 - 2 0 0 0}$ & \\
\hline \multirow{4}{*}{ Entidade } & Hospitais/Casas de saúde & 1 & 4 & 15 & 2 & 22 \\
\cline { 2 - 7 } & Órgáos na área da saúde & 19 & 24 & 13 & 1 & 57 \\
\cline { 2 - 7 } & Entidades profissionais & 1 & 2 & 4 & 6 & 13 \\
\cline { 2 - 7 } & Órgáo em outras áreas & 16 & 5 & 4 & 1 & 26 \\
\cline { 2 - 7 } & Mais de um espaço & 36 & 34 & 61 & 4 & 135 \\
\hline Total & & 73 & 69 & 97 & 14 & 253 \\
\hline
\end{tabular}

Fonte: Banco de dados da autora

no mercado de serviços médicos, nas instâncias de representação profissional e nos espaços de atuação, que em sua grande maioria eram públicos (hospitais públicos, universidades), a política eletiva se torna secundária para o ofício.

\section{Padróes de recrutamento e modalidades de investimento na medicina}

O estudo do processo de consolidação de uma elite médica a partir, exclusivamente, dos mecanismos objetivos de recrutamento desses profissionais, não é suficiente para compreender o perfil do profissional que diferentes contextos produziram. Dadas as dificuldades associadas à obtenção de informações sobre as origens sociais, sobretudo grau de escolaridade e ofício dos pais, tornou-se fundamental um exame mais apurado da dinâmica das famílias de elite e sua relação com a política e com a medicina, considerando os períodos históricos. Assim, recorremos à análise das trajetórias individuais inseridas nos grupos familiares para ter um melhor quadro dos padrões de recrutamento e das modalidades de investimento no ofício.

Tal análise nos permitiu a identificação de quatro grandes padróes de investimento na medicina que representam movimentos de maiores transformaçóes e ruptura e que estão associados a períodos históricos, perfis políticos, médicos e familiares distintos. O primeiro corresponde às trajetórias médicas cujo período de formação transcorre no período imperial até o início da República, mais precisamente no final do século XIX (1840-1889), e cujos respectivos grupos familiares eram descendentes de colonizadores portugueses e vinculados à oligarquia agrária proprietária de engenho e produtora de cana-de-açúcar, principal atividade econômica do estado. Dentre as famílias que se destacaram na medicina, nesse contexto, estão os Rollemberg, os Leite, os Rabello Leite e os Costa Dória. Nesse contexto, a medicina, assim como muitas outras profissóes, era o ofício de um pequeno grupo com posição econômica elevada, que viu nos títulos escolares uma estratégia de reprodução e manutenção de condição de elite. Em geral, as famílias que investiam na educação universitária dos filhos, em Sergipe, os encaminhavam para estudar medicina na Bahia ou direito em Recife, este último preferido ao primeiro em função do próprio caráter polivalente do título. Assim o direito, mais do que a medicina, constrói competências que podem ser mobilizadas em diversas situações e contextos e não se volta para um mercado exclusivo, mas permite reconversóes e usos diversos e múltiplos (Coradini, 2010). Contudo, a medicina adquiria também, nesse contexto, forte caráter político, e o conhecimento médico, obtido no interior das faculdades, era mobilizado para a intervenção política, para o controle das epidemias, para a capacidade de construção do Estado. Por isso, o tempo gasto com a clínica médica era bem menor quando comparado ao tempo gasto com a política e com as atividades da família. ${ }^{7}$

Um segundo padrão corresponde às trajetórias que transcorrem no final do século XIX, com o advento da República, e nas primeiras décadas do século XX. Demarcamos esse período porque a instauração da República fortaleceu a autonomia dos Estados, antigas províncias, garantindo a soberania das elites regionais por meio da "política dos governadores", implantada 
por Campos Sales em 1898. Apesar de extinguir os postos da Guarda Nacional, intensificou o poder dos coronéis na condução política dos municípios dos quais se originavam. Além disso, foi com a República que os serviços de saúde pública, sobretudo os sanitários, se expandiram permitindo aos médicos se colocarem a serviço do Estado. É nesse ínterim que se observa o intenso processo de institucionalizaçáo da medicina, que tem como principal elemento a relação entre a família Leite, os postos políticos locais e a profissionalização do ofício, com a criação de instituições e associações profissionais (1890-1940). Nesse contexto, o espaço privado de serviços médicos era precário e a medicina estava associada ainda a uma cultura geral ou política e por isso continuava sendo de fácil reconversão para ocupação de postos na burocracia pública, como veremos.

O terceiro padrão envolve as trajetórias que transcorreram após a década de 1940 e que estavam associadas à diversificação das origens sociais e a um maior investimento no mercado de serviços médicos. A principal característica desse padrão é o deslocamento das redes de base familiar, sustentadas pelos acordos entre as famílias dirigentes, para redes sustentadas pela amizade profissional e política. E, por fim, o último padrão corresponde às trajetórias profissionais que se desenvolvem após os anos 1980, cuja característica central é o investimento intenso num mercado privado de serviços médicos, ocupação de postos de direção em hospitais, laboratórios e clínicas particulares e hospitais públicos, atuação em instâncias de representação profissional, com ênfase para os conselhos, associaçôes e sociedades médicas.

Para o primeiro grupo, as trajetórias que transcorrem nesse contexto têm como principio básico as relaçóes sociais com base no sistema de parentela, ${ }^{8}$ uma vez que é esse sistema que fornece os critérios e as condiçôes de recrutamento da elite médica. Nesse período Sergipe vive o auge do cultivo da cana-de-açúcar, com o investimento no comércio internacional via a exportação desse produto. Comparado aos estados vizinhos, Bahia e Pernambuco, os engenhos de Sergipe eram de pequeno porte e ocupavam uma área territorial de pequena extensão, o que permitia a existência de vários engenhos em um mesmo município. Nessas condições, para dominar um município as famílias precisaram fazer alianças. Esse tipo de oligarquia que se formou não era exercido, portanto, por uma única família, mas por diversas famílias conectadas pelo casamento ou por vínculos políticos e de amizade, que dominavam todos os postos locais (médico, juiz, tabelião, inspetor, promotor, delegado, professor, vigário) a partir das alianças, fortalecendo a relação entre parentes e afins.

Entretanto, essa estrutura também estava baseada na forte concorrência entre "blocos de parentela" e suas alianças dependeram da mobilização de um conjunto de recursos que permitiram a distinção e hierarquização entre os grupos. A concentração de poder de uma parentela passou a depender, cada vez mais, dos bacharéis aptos a mobilizar seus saberes profissionais para ocupação de cargos municipais, estaduais e federais. E é dentro desse sistema de disputa entre grupos que o médico se situava, uma vez que estava nas mãos das parentelas o controle do município e de todos os cargos envolvidos.

Mas, mais do que isso, o bacharel representava a possibilidade de expansão das redes de relaçóes, pois, com a crescente urbanização da sociedade, a ampliação da máquina estatal, a expansão dos serviços públicos e a criação de novos postos, eles se tornaram fundamentais nas alianças que transcendiam à política local (Adorno, 1988; Blondel, 1957; Leal, 2012; Lewin, 1993; Pereira de Queiroz, 2006). As estratégias de conversão dos títulos acadêmicos em trunfos no espaço político foram cruciais para a manutenção desse sistema, garantindo à oligarquia agrária o controle político e diversificando a estrutura de capitais do grupo.

A principal característica da elite médica, nesse contexto, era a forte unidade e homogeneidade em termos de origens sociais, formação e atuação profissional, uma vez que descendia das elites rurais e agrárias, era treinada nas mesmas faculdades e voltava-se para um mercado político de cura, a partir do qual podia associar a medicina à intervenção em problemas de saúde pública. Contudo, era ao mesmo tempo segmentada e fragmentada, tendo em vista que esses médicos estavam divididos em "blocos de parentela" rivais.

Um exemplo de uma trajetória na medicina nesse período é a do médico Gonçalo Faro Rollemberg, 
o qual acumulava um duplo baronato pelo lado materno e cuja linhagem familiar remonta à história das propriedades rurais de Sergipe. Seu avô, o barão de Japaratuba, era enteado do baráo de Maruim, este último proprietário de três engenhos do eixo vale do Cotinguiba, que adquiriu, por meio do casamento e das alianças, liderança política entre os proprietários rurais dessa região. Seus pais eram primos, o que contribuiu para manter a família Rollemberg como umas das principais lideranças dos engenhos na região do Cotinguiba. Além disso, seu casamento com a filha do barão de Estância, herdeira do Engenho Escurial, um dos maiores concorrentes do vale do Cotinguiba, permitiu unir a produção de açúcar dos dois grandes eixos do estado.

Assim como muitos dos seus contemporâneos, exercia a medicina clínica eventualmente, chegando a produzir alguns artigos sobre hepatite e anestesia. Seu investimento concentrou-se na administração do engenho da família e na política, como deputado, senador e governador. Logo após concluir seu curso de medicina, em 1881, no Rio de Janeiro, assumiu o cargo de delegado de higiene em Japaratuba, regiāo em que sua família controlava os postos e onde construiu sua base política, e no mesmo ano foi eleito deputado provincial. Sua entrada na política e seus investimentos médicos dependeram das alianças da sua família, mas foram intensificadas por meio do sogro, o qual sucedeu na liderança do Partido Liberal elegendo-se vice-presidente da província e, logo em seguida, presidente. A liderança ocorria, por um lado, por meio das alianças locais e, por outro, pelas alianças regionais com dirigentes dos partidos. No caso de Gonçalo, no âmbito local liderou algumas oposições, aliando-se a chefes locais, e no âmbito regional as alianças familiares com o sogro (presidente do Partido Liberal) e seu tio (aliado político do sogro), um dos mais "expressivos líderes do Partido Liberal", (Dantas, 2009) lhe deram as condições de liderança política.

Outra característica fundamental das trajetórias nesse contexto era a mobilização de alianças estabelecidas fora do estado - geralmente durante o exercício dos mandatos de deputado federal ou senador ou durante a realização dos cursos de graduação - com políticos federais que poderiam dar suporte nas lutas e alianças locais. No caso de Gonçalo, no Senado da
República fez amizade e estreitou laços com o senador Nilo Peçanha, de quem obteve apoio em diferentes situaçóes. Uma dessas situações foi o movimento de Reação Republicana que representava os ideais de Nilo Peçanha e que em Sergipe teve como chefe local, eleito por Nilo, Gonçalo Rollemberg (Nascimento, 2007). A amizade instrumental com fins políticos desempenhou um papel central nos alinhamentos e acordos políticos, pois as relaçóes de base familiar, sustentadas nas alianças entre famílias, não garantiam mais a continuidade do controle político. Esse novo padrão de relaçôes emerge com a atuação dos bacharéis, responsáveis por conectar suas alianças individuais com as do seu grupo de origem, e ganha fôlego com o crescimento dos mercados profissionais, como veremos no padrão seguinte.

$\mathrm{O}$ segundo grupo corresponde às trajetórias que transcorrem nas primeiras décadas do século XX e que estão marcadas pela interseção entre a formação de um mercado de serviços médicos públicos e o investimento na política. Trata-se de uma geração que poderíamos denominar de “intermediários profissionais", não só por fazerem a conexão, como a geração anterior, entre uma periferia (Sergipe) e um centro (Rio de Janeiro) - contribuindo nesse caso para conectar espaços que pela distância geográfica não se comunicavam diretamente - mas também porque eram detentores de códigos, informaçôes e, sobretudo redes de relações que foram mobilizados para expansão dos mercados profissionais. A concorrência entre as parentelas no controle do jogo político e na luta por postos e cargos estatais, que se ampliaram no contexto da República, conduziu à atualização dos recursos e à progressiva expansão dos laços sociais. Essa diversificação foi essencial para garantir uma posição no bojo na "elite dirigente". Por circularem com facilidade, devido ao acúmulo de funçôes (senadores, médicos, burocratas) e por contarem com os recursos decorrentes disso, estabelecendo contatos e combinando vínculos, eles se tornaram agentes-chave, peças fundamentais na formação de um mercado médico.

A formação e expansão de um espaço de atuação profissional promovem uma nova forma de sobrevivência econômica dos grupos e também uma nova possibilidade de articulação política. Por meio da organização dos ofícios e do exercício da profissão 
vão se constituindo novas redes de relaçóes que são mobilizadas tanto para promover uma carreira na política quanto para ampliar o espaço de atuação profissional. Para se manter, as parentelas precisaram unir forças e diminuir o peso dos conflitos internos e das rivalidades entre os chefes locais. Agora eles precisavam colaborar e a criaçáo das associaçóes de representação de classe constituiu um elemento fundamental para a manutenção da sua existência e uma estratégia para diminuir a competição. Assim, as instituições se tornavam, muitas vezes, espaços de convivência e mediação entre grupos pertencentes a parentelas diversas (Pereira de Queiroz, 1976; Trigo, 2001).

O segundo exemplo é o caso da trajetória do médico Augusto César Leite, que se destacou na medicina e na política sergipanas nas primeiras décadas do século XX pelo seu papel no processo de institucionalização e formação de um mercado médico, fundando a faculdade de medicina, além de diversos hospitais, maternidades, casas de serviços médicos, centros de saúde e instituições de representação profissional. Sua trajetória se caracteriza pela intensa articulação entre medicina e política, investindo ao mesmo tempo em instâncias de representação e consagração médicas e na carreira política como senador. Formado em 1909 pela Faculdade de Medicina do Rio de Janeiro, era filho de um chefe político local que chegara a intendente municipal. Sua família era proprietária de engenho, considerado de médio porte para o período, e vinculada a alianças familiares decorrentes tanto das uniōes matrimoniais quanto das amizades políticas.

A primeira figura importante na trajetória de Augusto César Leite foi o irmão, Silvio Leite, também médico, e que integrava a parentela dos "Leite de Riachuelo". Sílvio Leite fundou o Hospital de Caridade da cidade, que hoje recebe seu nome, e fixou-se no município de Riachuelo, base política da família, onde atuou como delegado de higiene e político. Assim, quando Augusto César Leite ingressou na carreira médica e política sua rede de base familiar já o conectava às elites sergipanas que tentavam controlar os postos políticos.

A segunda figura importante foi o desembargador Simeão Teles de Meneses Sobral - aliado político da família que compunha a "parentela dos Rollemberg"
- presidente do Hospital Santa Isabel, que o convidou a ingressar no corpo clínico do referido hospital. Esse personagem era tio do médico descrito no grupo anterior, o que conecta Augusto César Leite à família Rollemberg e ao seu grupo de aliados, visto que eram eles que controlavam os postos. É dentro desse hospital que Augusto César Leite fortalece os vínculos profissionais, estabelece novas amizades e fomenta a idéia de criação de um novo hospital na cidade de Aracaju, que deveria ser administrado por médicos e não mais por políticos, como era feito até entâo. Com alguns colegas desse hospital, e de outros espaços em que atuava, funda a Sociedade de Medicina e Cirurgia de Sergipe, em 1919. A participação na fundação dessa entidade, junto com Francisco Pimentel Franco, seu colega do Hospital Santa Isabel, e Eronides Carvalho, diretor-geral de Higiene e Saúde Pública do estado, lhe permitiu ocupar uma posição importante na liderança da comunidade médica, fundamental para a criação do Hospital Cirurgia. Assim ele passa a exercer um papel significativo na articulação dos médicos e na institucionalização da medicina no estado, contribuindo para criação de hospitais, maternidades, centros médicos e associaçóes profissionais. Um dos efeitos disso foi a emergência das estruturas organizacionais de saúde pública, como hospitais e clínicas, e a criação de papéis ocupacionais.

A terceira figura influente na rede de relaçôes de Augusto foi o irmão Júlio Leite. O casamento do irmão com a filha do dono da Usina Pedras (Gonçalo das Pedras), a mais importante do estado, também proprietário da maior indústria têxtil de Sergipe, fortalece os laços entre sogro e genro e permite a aliança entre famílias. Júlio Leite, que era bacharel em direito, intensifica sua atuação na política pela relação com o sogro, tornando-se delegado de polícia, ocupando vários cargos estatais (chefe de polícia, inspetor escolar, diretor de serviços de água e saúde) até se tornar secretário-geral do estado e senador da República. Dessa união entre irmãos, sogro e genro nasce um novo agrupamento político, coordenado por Augusto César Leite e que tinha como órgão oficial o jornal O Estado de Sergipe (Leite, 2008). Tais relações foram fundamentais para fornecer os recursos materiais para organização do mercado de serviços de saúde pública. A criação do Hospital Cirurgia e da 
Maternidade Francino Melo, ambos públicos, contou com o patrocínio dos aliados de Júlio Leite. Está ainda vinculada às suas redes a criação de outras instituiçóes de saúde pública: Hospital Infantil, Centro Materno Infantil, Casa Maternal Amélia Leite.

Em 1935, Augusto elegeu-se senador, o médico Eronides Carvalho (aliado profissional) governador e Julio Leite (irmão) secretário-geral do governo. Nesse contexto lideraram vários cargos: o primo, também médico, Moacir Rabelo Leite, é diretor do Banco Mercantil de Sergipe e vários cargos de interventores municipais são ocupados por aliados. Nessas condiçóes a parentela "Leite" ocupa os principais postos até os anos 1960.

Essas circunstâncias contribuíram para sua entrada efetiva na carreira política e seu intenso investimento na institucionalização da medicina em Sergipe. Suas alianças demonstram que as conexóes de base familiar continuaram importantes e onde esses laços já não mais ofereciam garantias, uma alternativa aberta foi a amizade política, constituída na faculdade de medicina e nos espaços de atuação profissional. Em torno do mercado médico vão se constituindo novas formas de recrutamento político e alianças. Além disso, a diversificação econômica do grupo, investindo ao mesmo tempo na indústria, nos mercados profissionais e nos cargos estatais permite a essas elites dirigentes sua reorganização política. A amizade profissional é conectada à política, fortalecendo suas bases e expandindo horizontalmente suas relaçóes.

Diante desse quadro, para preservar sua posição no espaço do poder, cada vez mais ameaçada pela competitividade, não restou outra saída às famílias dirigentes senão investir em espaços institucionais capazes de possibilitar a formação de novas redes e novos espaços de atuação.

O terceiro padrão corresponde às trajetórias cujo período de formação ocorre após a década de 1940 e que estão associadas a uma maior diversificação das origens sociais e geográficas. Esse é o contexto em que se observa um maior número de médicos vindos de fora do estado, 35\% deles, predominantemente de estados do Nordeste. Tal fato se deve, por um lado, à ampliação dos postos ocupados pelos médicos, sobretudo nos serviços de saúde pública, o que conduzia a uma diversificação no processo de recrutamento, visto que os médicos locais não davam conta do preenchimento de tais postos. Por outro lado, os laços construídos, principalmente com a Bahia, conduziram à prática comum de recrutar jovens formandos na Faculdade de Medicina da Bahia.

Aqui se destaca a trajetória dos irmãos Hugo e Hyder Gurgel, os quais representam a expansão das redes de relaçôes que, nesse caso, não se baseiam exclusivamente num sistema de parentelas, mas numa diversificada e complexa rede que inclui políticos e médicos. Originários do interior do estado do Ceará e filhos de comerciantes, o primeiro irmão a estabelecer-se como médico em Sergipe chega, em 1947, a convite de um professor da Faculdade de Medicina da Bahia, Almir Oliveira. Esse professor era amigo de Benjamim Carvalho, então diretor do Hospital Cirurgia, que se dirigiu até a Bahia para recrutar um médico obstetra para atuar no hospital em Aracaju. Tal indicaçâo lhe rendeu um cargo na maternidade Francine Melo, do referido hospital, então dirigida por Augusto César Leite. Os laços políticos e de amizade profissional entre os médicos Augusto César Leite, Benjamim Carvalho e Almir Oliveira estão na origem da sua indicação e chegada em Sergipe. O que se pode observar é que esse contexto dos anos 1950 é caracterizado pela mudança na forma de recrutamento para os postos médicos, fundada agora em redes de relaçóes mais amplas, consolidadas, dentre outros elementos, principalmente pela amizade profissional. Já Hyder Gurgel, também formado pela Faculdade de Medicina da Bahia, foi recrutado pelas redes profissionais de seu irmão Hugo e chega a Aracaju para ocupar um cargo de pediatra no Hospital Cirurgia. A carreira dos irmãos Gurgel é pautada pelo intenso investimento em postos médicos, voltados à clínica e aos espaços de representação profissional, chegando a ocupar a presidência de órgãos como o Conselho Regional de Medicina e participando da fundação das sociedades associadas as suas especialidades (ginecologia e pediatria). Além disso, suas carreiras demonstram um deslocamento dos laços familiares, sustentados pelo sistema de parentela, para laços de amizade profissional, formados no exercício do ofício. Isso permitiu uma expansão horizontal, ampliando o alcance das conexões e permitindo a formação de 
um mercado, com ênfase na expansão de espaços médicos privados de atuação, com a criação de clínicas e hospitais particulares. É essa geração que, na década de 1970, funda as principais clínicas e hospitais privados do estado de Sergipe.

Tais condiçóes contribuem para criar também, a partir da década de 1940, um novo tipo de profissional que passa a viver da medicina, forma sua clientela e redes por meio do ofício e as mobiliza para entrada na política. Ao contrário do que acontecia com as geraçóes anteriores, cuja clientela para política não dependia da medicina, mas das relaçóes e alianças entre famílias, essa geração toma o exercício da medicina como estratégia para acumular capital social. É dentro dessa configuração que se passa de um sistema de dominação onde o que conta são as relaçóes entre parentes e afins para um modelo cuja lógica centra-se na amizade política e profissional.

E, por fim, a geração dos formados pós-anos 1980 cuja característica central é a de uma elite local, formada em Sergipe, nascida em Aracaju, com fortes raízes urbanas e com origens sociais mais diversificadas. Além disso, começam suas carreiras predominantemente na capital $(52 \%)$, embora o interior continue sendo atrativo para darem o impulso na carreira (36\%). Os cargos de direção exercidos são voltados para a área médica, com destaque para as entidades de representação profissional, hospitais e clínicas particulares e com forte acúmulo de posições em vários desses espaços concomitantemente. Alguns deles são herdeiros profissionais, tendo na relação familiar não só o sentimento de vocação, mas o espaço de transmissão das redes e dos vínculos.

Dois conjuntos de questôes podem ser observados a partir disso: primeiro, os padróes de conexão entre laços familiares e investimentos na medicina no interior dos grupos dominantes. Segundo, o enfraquecimento dos laços familiares na organização da medicina, as mudanças no recrutamento profissional e a formação de uma rede de relações médicas que passa a controlar o mercado de serviços médicos. Portanto, o controle dos postos médicos, que antes estava nas mãos das parentelas, se desloca para as redes de relaçóes, cuja tendência é a sua expansão para além das relações familiares e que envolvem, sobretudo a amizade profissional. Usando aqui uma expressão de Carvalho
(2007), podemos dizer que essa elite passa de uma situação de parentela para seguir "a caminho do clube".

\section{Consideraçóes finais}

Este artigo procurou demonstrar as condições sociais que tornam possível a ascensão a uma posição dominante no âmbito da medicina. Se, por um lado, a sociologia dos grupos profissionais não tomou como problemática a relação entre grupos dirigentes e ofícios, por outro lado, a sociologia das elites tampouco considerou a formação dos dirigentes profissionais, dando mais atenção às elites políticas, de modo geral.

Com o intuito de contribuir para o exame da relação entre grupos dirigentes e elites profissionais, tomamos como preocupação central os processos de recrutamento da elite médica a partir do exame das propriedades sociais e do processo de acumulação de recursos capazes de garantir a entrada e permanência nas posiçôes de poder. O estudo da elite médica, de modo geral, e as próprias particularidades da recomposição dos grupos dominantes em contextos periféricos como o de Sergipe, permite aprofundar a combinação entre estrutura de reprodução social das elites e investimento em determinados espaços profissionais. Nessas condiçóes, a forte rivalidade produzida no interior dos grupos dirigentes e a sua fragmentação, em parte decorrente dos conflitos, conduziram a expansão dos vínculos e um direcionamento para os laços produzidos a partir do universo profissional.

Dentro desse quadro, o uso da prosopografia, como ferramenta metodológica, permitiu a construçáo de perfis sociais das elites médicas e suas variaçóes longitudinais, que possibilitaram o entendimento dos mecanismos de recrutamento, das condiçóes de seleção e da reprodução desse grupo. As mudanças observadas na composição social dos médicos foram na grande maioria gradativas. Os movimentos de maiores rupturas e as possibilidades de renovação, tanto no que diz respeito às origens quanto à dinâmica do ofício, considerando os intervalos históricos, foram observados a partir da década de 1940 .

Contudo, é preciso ainda associar a prosopografia a um exame das condiçóes históricas, para que seja possível articular as mudanças na composição social 
dos médicos com os contextos sociais a partir dos quais emergem. Com isso é possível observar que no século XIX e nas primeiras décadas do século XX o recrutamento dos médicos ocorria por meio das redes de relaçóes de base familiar, inscritas no sistema de parentela, que eram capazes de mobilizar. Nessas condiçóes, o título de bacharel teve um papel central na expansão e renovação das parentelas, conduzindo a elite médica sergipana a coincidir com as elites sociais, econômicas, políticas e intelectuais da época. $\mathrm{O}$ pertencimento a essas redes de parentelas e aos postos por elas definidos permitiu a dedicação, predominante, à atividade política e agrária e a definição do ofício médico voltada para sua vocação política e de intervenção na saúde pública.

Ao longo do século XX, a cooptação continua associada a esse sistema, mas passa a depender, cada vez mais, da amizade profissional, cujo peso se intensifica na medida em que se amplia o mercado médico. É dentro desse quadro que pode se observar uma distinção entre estas elites (médicas, políticas, sociais, econômicas), sobretudo após os anos 1940. Isso dependeu primeiro, das transformações na composição das próprias elites políticas e o acesso, cada vez maior, de indivíduos de classe média a cargos públicos, tornando a carreira política um meio de ascensão social (Conniff, 2006). Segundo, das mudanças na composição na elite médica e o acesso, ainda que tímido e suave, de indivíduos pertencentes aos extratos médios à carreira médica. Essa tendência permitiu certo grau de diferenciação entre as elites, contribuindo para a emergência de novas formas de lideranças médicas. $\mathrm{E}$ ainda, por fim, com a expansão e consolidação do mercado de serviços médicos e o fortalecimento das respectivas instâncias de representação profissional, o acesso à condição de elite passou a depender mais das redes de bases profissionais, o que contribuiu para fechar os médicos em um círculo de relações cujo cimento foi a amizade profissional. É a partir desse momento que eles conquistaram a capacidade de viver do ofício médico.

Assim, espaços como as entidades profissionais, as universidades e o próprio mercado clínico privado (hospitais, laboratórios, consultórios) se tornaram espaços privilegiados não só de formação de um saber, mas, sobretudo, de formação de uma rede possível de ser acessada para entrada e ascensão no mercado e não mais apenas para atuação política, como ocorria nos períodos anteriores à existência de um mercado de serviços médicos.

\section{Notas}

1 As clássicas oposições entre Wright Mills e Robert Dahl resultaram em contraposiçóes teóricas representadas, por um lado, pelo problema das relaçóes de classe e posição de dominação, enfrentado por Mills, por outro lado, pelos estudos de demonstração empírica do poder propostos por Dahl. Essas oposiçóes demarcaram duas formas distintas de abordagem. A abordagem elitista, que trazia na linha de frente Mills, dentre outros autores, tinha por objetivo demonstrar a capacidade de dominação das elites e as posiçôes privilegiadas ocupadas. O problema estava na relação entre classe e posição nos postos de comando no governo nacional. E, num outro pólo, a abordagem pluralista, representada por Dahl, que visava demonstrar empiricamente que os poderes das elites eram, fundamentalmente, flutuantes. A oposição entre "elitistas" e "pluralistas" resultou em trabalhos diversificados e fez emergir objetos voltados, fundamentalmente, ao poder político, tais como: grupos de pressão; lobbies, democracia, dentre outros (Riesman, Glazer e Denney, 1971).

2 Em âmbito internacional destaca-se o trabalho de Weisz (1988) sobre a Academia Francesa de Medicina. Esse autor observou que, para o caso da França, a entrada na Academia Francesa de Medicina passou a depender menos dos laços de família e cada vez mais da posição obtida, baseada na forte competição, dentro de uma hierarquia rígida de postos. Em âmbito nacional, podemos citar os trabalhos de Coradini (1996, 2005) sobre as condições de seleção de uma elite profissional e o papel das relaçóes de reciprocidade para o acesso a posiçôes em espaços de representação médica, como a Academia Nacional de Medicina.

3 Uma análise detalhada da dinâmica dos municípios sergipanos nesse período pode ser encontrado em Dantas (2004).

4 Há uma vasta bibliografia que relaciona o coronelismo com um sistema de domínio de chefes políticos locais. Sobre isso ver Leal (2012), Pereira de Queiroz (2006) e Lewin (1993).

5 Para elite periférica seguimos a orientação de Love (1982) o qual aponta como característica central desse tipo de elite a distância com relação aos estados política e economicamente dominantes.

6 Uma análise mais detalhada da relação entre elites médicas e elites regionais pode ser encontrado em Petrarca $(2017,2019)$. 
7 Como mostra Coelho (1999), o tempo gasto com a medicina clínica, com os consultórios, em meados do século XIX, no Rio de Janeiro, não era mais do que três horas diárias.

8 Trata-se de uma dinâmica marcada pelo domínio dos proprietários rurais - que eram chefes políticos locais denominados também de coronéis - e baseada nos arranjos, muitas vezes incertos e instáveis, entre famílias e afins (aliados políticos, afilhados, amigos). A "política de parentela”, que emerge desse sistema, representa a força desses chefes políticos locais e seus aliados nos agrupamentos políticos e sua influência nas demais esferas da vida social (Leal, 2012 ; Levine, 2006; Pang, 1979; Queiroz, 1976).

\section{BIBLIOGRAFIA}

ADORNO, Sérgio. (1988), Os aprendizes do poder: $o$ bacharelismo liberal na politica brasileira. Rio de Janeiro, Paz e Terra.

BARICKMAN, Bert \& LOVE, Joseph. (2006), "Elites regionais", in F. HEINZ (org.), Por outra história das elites, Rio de Janeiro, Editora FGV.

BECKER, Howard. (1961), Boys in white. Chicago, University of Chicago Press.

BLONDEL. Jean. (1957), As condiçóes sociais da vida politica na Paraíba. Rio de Janeiro, Editora FGV.

BOIGEOL, Anne \& DEZALAY, Ives. (1997), "De l'agent d'affaires au barreau: conseils juridiques et la construction d'un espace professionnel". Genèses: Sciences Sociales et Histoire, 27 (juin): 49-68.

BOLTANSKI, Luc. (1982), Les cadres: la formation d'um groupe social. Paris, Les Éditions de Minuit.

BOURDIEU, Pierre. (1984), Homo academicus. Paris, Les Éditions de Minuit.

BOURDIEU, Pierre. (1989), La noblesse d'Etat. Paris, Les Éditions de Minuit.

CARNEIRO, Mauro Brandão \& GOUVEIA, Valdiney Veloso (coord.). (2004), O médico e o seu trabalho: aspectos metodológicos e resultados do Brasil. Brasília, Conselho Federal de Medicina.

CARVALHO, José Murilo. (2007), A construção da ordem: a elite politica imperial. 3a edição, Rio de Janeiro, Civilização Brasileira.

CHARLE, Christophe. (2006), “Como anda a história social das elites e da burguesia? Tentativa de balance crítico da historiografia contemporânea", in F. HEINZ (org.), Por outra história das elites, Rio de Janeiro, Editora FGV.

CICCOUREL, Aaron. (2002), Le raisonnement médical. Paris, Éditions du Seuil.

COELHO, Edmundo. (1999), As profissóes imperiais: medicina, engenharia e advocacia no Rio de Janeiro, 1822-1930. Rio de Janeiro, Record.

CONNIFF, Michael. (2006), "A elite nacional", in F. HEINZ (org.), Por outra história das elites, Rio de Janeiro, Editora FGV.

CORADINI, Odaci Luiz. (1996), “Grandes famílias e 'elite profissional' na medicina no Brasil”. História, Ciências, Saúde - Manguinhos, 3 (3): 425-466.

CORADINI, Odaci Luiz. (2005), "A formação da elite médica, a Academia Nacional de Medicina e a França como centro de importaçáo". Estudos Históricos, 1 (35): 3-22.

CORADINI, Odaci Luiz. (2008), "As elites como objeto de estudos", in O. L. CORADINI (org.), Estudos de grupos dirigentes no Rio Grande do Sul, Porto Alegre, Editora UFRGS.

CORADINI, Odaci Luiz. (2010), “Titulação escolar, condição de 'elite' e posição social. Revista Brasileira de Educação, 15 (43): 45-69.

DANTAS, Ibaré. (2004), História de Sergipe república, 1889-2000. Rio de Janeiro, Tempo Brasileiro.

DANTAS, Ibaré. (2009), Leandro Ribeiro de Siqueira Maciel: o patriarca do Serra Negra e a politica oitocentista em Sergipe, 1825-1909. Aracaju, Criação.

DEZALAY, Ives \& GARTH, Bryan. (2000), "A dolarização do conhecimento técnico-profissional do Estado: processos transnacionais e questóes de legitimação na transformação do Estado, 1960-2000”. Revista Brasileira de Ciências Sociais, 15 (43): 163-176.

DEZALAY, Ives \& GARTH, Bryan. (2002), La mondialisation des guerres de palais. Paris, Éditions du Seuil.

EDLER, Fabio. (1998), "A medicina brasileira no século XIX: um balanço historiográfico". Asclepio, L (2): 169-186.

EDLER, Fabio. (2002), "A Escola Tropicalista Baiana: um mito de origem da medicina Tropical no Brasil". História, Ciências, Saúde - Manguinhos, 9 (2): 357-385. 
FREIDSON, Elliot. (2009), A profissão médica. São Paulo, EdUnesp.

HALL, Oswald. (1948), "The stages of a medical career". The American Journal of Sociology, 53 (5): 327-336.

HEINZ, Flávio. (2006), Por outra história das elites. Rio de Janeiro, FGV.

HUGHES, Everett. (1955), "The making of a physician". Human Organization, 14 (4): 21-25.

LEAL, Vitor Nunes. (2012), Coronelismo, enxada e voto: o município e o regime representativo no Brasil. $4 \mathrm{a}$ edição, São Paulo, Companhia das Letras.

LEBARON, Frederic. (2001), O campo dos economistas franceses no fim dos anos 90: lutas de fronteiras, autonomia e estrutura. Mana, 7 (1): 9-29.

LEITE, Ricardo. (2008), Júlio Leite: o chefe invisivel., 2a edição, Aracaju, Triunfo.

LEVINE, Robert. (2006), "Pernambuco e a Federação brasileira", in B. Fausto et al., História geral da civilização brasileira, 1889-1930. Rio de Janeiro, Bertrand Brasil.

LEWIN, Linda. (1993), Política e parentela na Paraiba: um estudo de caso da oligarquia de base familiar. Rio de Janeiro, Record.

LOVE, Joseph. (1982), A locomotiva: São Paulo na federação brasileira, 1889-1937. Rio de Janeiro, Paz e Terra.

MACHADO, Maria Helena. (1997), Os médicos no Brasil: um retrato da realidade. Rio de Janeiro, Editora Fiocruz.

NASCIMENTO, Sayonara R. do. (2007). Representação da reação republicana em Sergipe: a campanha oposicionista do Jornal do Povo ao governo Pereira Lobo (1921-1922). Revista do Instituto Histórico de Sergipe, 36: 109-134.

PANG, Eul-Soo. (1979), Coronelismo e oligarquia (1889-1943): a Bahia na Primeira República. Rio de Janeiro, Civilização Brasileira.

PETRARCA, Fernanda Rios (2017), "De coronéis a bacharéis: reestruturação das elites e medicina em Sergipe, 1840-1900". Revista Brasileira de História, 37 (74): 89-112.
PETRARCA, Fernanda Rios (2019). "Entre jalecos, bisturis e a arte de fazer política”. História, Ciências, Saúde-Manguinhos, 26 (2): 573- 591.

PETRARCA, Fernanda Rios. (2010), “Construção do Estado, esfera política e profissionalização do jornalismo no Brasil”. Revista de Sociologia e Politica, 18 (35): 81-94.

PINÇON, Michael \& PINÇON-CHARLOT, Monique. (2003), "A infância dos chefes: a socialização dos herdeiros ricos na França”, in A. ALMEIDA \& M. NOGUEIRA (orgs.), A escolarização das elites: um panorama internacional da pesquisa, Petrópolis, Vozes.

QUEIROZ, Maria Isaura Pereira de. (1976). O mandonismo local na vida política brasileira e outros ensaios. São Paulo, Alfa-Ômega.

QUEIROZ, Maria Isaura Pereira de. (2006), "Coronelismo numa interpretação sociológica”, in B. Fausto et al., História da civilização brasileira, Rio de Janeiro, Bertrand Brasil.

RAMALHO, José Ricardo \& SANTANA, Marco Aurélio. (2010), Sociologia do trabalho no mundo contemporâneo. 3a edição, Rio de Janeiro, Jorge Zahar.

RIEFFEL, Rémi. (1984), L’élite des journalistes. Paris, Presses Universitaires de France.

RIESMAN, David; GLAZER, Nathan \& DENNEY, Reuel. A multidão solitária: um estudo da mudança do caráter americano. São Paulo, Perspectiva, 1971.

ROY, Fernand \& SAINT-PIERRE, Jocelyn. (2006), "A alta redação dos jornais de Quebec, 1850-1920”, in F. HEINZ (org.), Por outra história das elites, Rio de Janeiro, Editora FGV.

SANTANA, Samarone. (2009), Dicionário biográfico de médicos de Sergipe: séculos XIX e XX. Aracaju, Academia Sergipana de Medicina.

SAPIRO, Gisele. (2004), "Elementos para uma história do processo de autonomização: o exemplo do campo literário francês". Tempo Social, 16 (1): 93-105.

TRIGO, Maria Helena. (2001), Ospaulistas de quatrocentos anos: ser e parecer. São Paulo, Annablume.

WEISZ, George (1988). "Les transformations de l'élite médicale en France". Actes de la Recherche en Sciences Sociales, 74: 33-46. 


\section{COMPOSIÇÁOO SOCIAL, CRITÉRIOS DE SELEÇÃO E LÓGICAS DE RECRUTAMENTO DA ELITE MÉDICA EM SERGIPE}

\section{Fernanda Rios Petrarca}

Palavras-chave: Elites; Medicina; Política; Recrutamento.

$\mathrm{O}$ artigo analisa os critérios de seleção profissional e as lógicas de recrutamento das elites médicas sergipanas, baseado no exame das propriedades sociais dos seus membros. Com uso do método prosopográfico, demonstra-se as mudanças sociográficas, as variaçóes longitudinais e as credenciais dos médicos que ocuparam os cargos e as posiçóes mais elevadas nesse espaço profissional e cujas carreiras foram consideradas exitosas pelos seus pares. Uma das principais constataçóes é a de que as mudanças na composição da elite médica e suas dinâmicas de renovação foram observadas, sobretudo, a partir da década de 1940 e representam um momento importante de afastamento progressivo dos médicos da atividade política e um investimento intenso no mercado privado de serviços de saúde. Esses movimentos de ruptura expandiram o espaço de atuação profissional, conduzindo ao fortalecimento de instâncias de representaçáo e a valorização das redes de base profissional para o acesso à condição de elite.

\section{SOCIAL COMPOSITION, SELECTION CRITERIA AND RECRUITMENT LOGIC OF THE MEDICAL ELITE IN SERGIPE}

\section{Fernanda Rios Petrarca}

Keywords: Elites; medicine; politics; recruitment.

This articles analyses the criteria of professional selection and the recruitment logic of the medical elite from Sergipe, based on the exam of social properties of its members. Using the prosopographic method, we present the sociographic changes, longitudinal variations, and credentials of the physicians who occupied the positions and the highest positions in this professional space and whose careers were considered successful by their peers. One of the main findings is that the changes in the composition of the medical elite and their dynamics of renewal were observed, especially since the 1940s, and represent a crucial moment for doctors' progressive removal from political activity and acute investment in the market of private health services. These disruptive movements expanded the scope of professional practice, leading to the strengthening of instances of representation and the enhancement of professionally based networks for access to elite status.

\section{COMPOSITION SOCIALE, CRITÈRES DE SÉLECTION ET LOGIQUES DE RECRUTEMENT DE LÉLITE MÉDICALE À SERGIPE}

\section{Fernanda Rios Petrarca}

Mots-clés: Élites; Médecine; Politique; Recrutement.

Larticle analyse les critères de sélection professionnelle et les logiques de recrutement des élites médicales de l'état de Sergipe. Nous nous basons, pour cela, sur l'examen des caractéristiques sociales de ses membres. En utilisant la méthode prosopographique, nous démontrons les changements sociographiques, les variations longitudinales et les titres relatifs aux compétences des médecins qui occupaient les postes et des fonctions plus élevées dans cet espace professionnel et dont les carrières étaient considérées comme réussies par le leurs pairs. L'une des principales conclusions est que des changements dans la composition de l'élite médicale et ses dynamiques de renouvellement ont été observés, surtout à partir des années 1940, et représentent un moment important de retrait progressif des médecins de l'activité et un investissement intense dans le marché privé des services de santé. Ces mouvements de rupture ont élargi l'espace d'action professionnel, conduisant au renforcement des instances représentatives et à la valorisation des réseaux professionnels pour l'accès à la condition d'élite. 